\title{
Congenital tethered cord in adults with concomitant lipoma of filium terminale - case report
}

\author{
Wrodzony zespół zakotwiczonego rdzenia u dorosłych \\ z towarzyszącym tłuszczakiem nici końcowej - opis przypadku \\ Rafał Staszkiewicz'1, Waldemar Och ${ }^{1}$, Wiesław Strohm ${ }^{1}$, Jan Miodoński', Adrian Kotas², Wiesław Marcol ${ }^{3}$ \\ 15th Military Hospital with Polyclinic in Cracow, Poland \\ 2Department of Neurosurgery, 2nd Voivodeship Specialist Hospital in Jastrzębie Zdrój \\ ${ }^{3}$ Department of Physiology, School of Medicine in Katowice, Medical University of Silesia, Katowice, Poland
}

\section{ABSTRACT}

Congenital adult tethered cord syndrome (TCS) with accompanying lipoma is a rare disease in adults and difficult to diagnose. Surgical treatment is difficult and can lead to many complications.

The authors present a case of a 26-year-old woman with a large filium terminale lipoma and tethered cord at the S2 level. The patient complained of pain in the lumbosacral region of the spine, moderate incontinence, and a right-sided foot drop with impaired sensation.

Diagnostics were performed using magnetic resonance imaging (MRI). The patient underwent a surgical procedure untethering the spinal cord with a partial lipoma resection. Microsurgical techniques were used during the procedure and intraoperative neurophysiological monitoring was performed.

In the postoperative observation, the pain in the lumbosacral region of the spine was reduced, and some of the sensory disturbances subsided. However, there was no significant improvement in the foot muscle strength.

Long-term symptoms such as lumbosacral pain, sensory disturbances and poor urinary incontinence are not characteristic symptoms that clearly indicate tethered cord syndrome. Surgical treatment in this case is a difficult procedure due to the nature and location of changes in the environment of the cauda equina. Another serious problem is identifying the filium terminale. Surgical operation is associated with postoperative fluid fistula with impaired surgical wound healing.

The outcome of the surgery is not always satisfactory for the patient, as the only treatment effect can be to stop the progressive neurological symptoms.

\section{KEY WORDS}

tethered cord syndrome, terminale filium, lipomyelomeningocele

\footnotetext{
Received: 07.10.2016

Revised: 23.10 .2016

Accepted: 29.11.2017

Published online: 26.10 .2018

Addres for correspondence: Dr hab. n. med. Wiesław Marcol, Department of Physiology, School of Medicine in Katowice, Medical University of Silesia, Katowice, Poland, ul. Medyków 18, 40-752 Katowice-Ligota, tel. + 483225250 87, e-mail: fzjkatpl@sum.edu.pl

Copyright $\odot$ Śląski Uniwersytet Medyczny w Katowicach

www.annales.sum.edu.pl
} 


\section{STRESZCZENIE}

Wrodzony zespół zakotwiczonego rdzenia u dorosłych (tethered cord syndrome - TCS) z towarzyszącym tłuszczakiem jest chorobą rzadko występującą u dorosłych i często sprawia problemy diagnostyczne. Leczenie operacyjne jest trudne i może prowadzić do licznych powikłań.

Autorzy przedstawiają przypadek 26-letniej kobiety z olbrzymim tłuszczakiem nici końcowej i zakotwiczonym rdzeniem na poziomie S2. Pacjentka skarżyła się na bóle okolicy lędźwiowo-krzyżowej kręgosłupa. Ponadto obserwowano umiarkowanego stopnia nietrzymanie moczu i prawostronne opadanie stopy z zaburzeniami czucia.

Diagnostykę przeprowadzono za pomocą rezonansu magnetycznego. Chora przeszła zabieg chirurgiczny uwolnienia rdzenia kręgowego z częściową resekcją tłuszczaka nici końcowej. Podczas zabiegu stosowano techniki mikrochirurgiczne oraz posiłkowano się neuromonitoringiem śródoperacyjnym.

W obserwacji pooperacyjnej u chorej zmniejszyły się dolegliwości bólowe okolicy lędźwiowo-krzyżowej kręgosłupa, ustąpiły także częściowo zaburzenia czucia. Nie obserwowano natomiast znacznej poprawy siły mięśniowej stopy.

Długo trwające objawy, takie jak bóle kręgosłupa w odcinku lędźwiowo-krzyżowym, zaburzenia czucia, a także słabo zaznaczone objawy nietrzymania moczu, nie są objawami jednoznacznie wskazującymi na zespół zakotwiczonego rdzenia. Leczenie operacyjne w takim przypadku jest procedurą trudną ze względu na charakter i lokalizację zmiany w otoczeniu ogona końskiego. Innym poważnym problemem jest identyfikacja nici końcowej. Zabieg operacyjny obarczony jest wystąpieniem pooperacyjnej przetoki płynowej z zaburzeniem gojenia rany operacyjnej.

Wynik zabiegu operacyjnego nie zawsze jest dla chorego satysfakcjonujący, ponieważ jedynym efektem leczenia może być zatrzymanie postępujących objawów neurologicznych.

\section{SŁOWA KLUCZOWE}

zespół zakotwiczonego rdzenia, nić końcowa, przepuklina oponowo-rdzeniowa z tłuszczakiem

\section{INTRODUCTION}

Tethered cord (TC) pathology refers to every low situated conus medullaris (lower than the second lumbar vertebrae or below the L1-L2 disc space) [1].

Nevertheless, there are patients with symptoms of tethered cord whose conus medullaris is located at the correct height [2].

Tethered cord syndrome (TCS) is an uncommon disease with a reported incidence of 0.05 to 0.25 cases per 1000 births [3].

Lipoma, posttraumatic or postoperative scar tissue are among the most frequent causes of the pathology [4].

Congenital TC is an effect of aberrant embryogenesis during the differentiation of cells of the caudal region. The part of caudal region cells, developed in earlier stages of embryogenesis, undergoes apoptosis, forming filium terminale, sacrococcygeal ligament and ventriculus terminalis of the conus [5].

Filium terminale lipoma and 'fatty filium' are both the products of improper apoptosis [2].

The set of symptoms and signs, which are the consequence of tethered cord and are caused by hypoxia in stretched tethered cord, are called the tethered cord syndrome. Such hypoxia results from an inefficient blood supply [6]. Tethered cord symptoms include orthopedic urologic and neurologic problems. The most common findings are cutaneous signs in the lumbar area, neurogenic bladder with incontinence and/or urinary tract infections [7]. Pain is the major symptom in the adult tethered cord syndrome population [5].

Leg or foot weakness, numbness or spasticity, foot deformity (pes cavus, claw toes), spinal deformities, nondermatomal leg and back pain are far less common in adults [7]. Tethered cord patients are divided in four categories based on TCS pathophysiology (Tab. I) [8]. The patient presented in this paper belongs to group 1 .

Table I. Tethered cord syndrome categories according to new classification of spinal lipomas based on embryonic stage [8]

Tabela I. Kategorie zespołu zakotwiczonego rdzenia kręgowego na podstawie nowej klasyfikacji tłuszczaków rdzenia kręgowego opartej na rozwoju embriologicznym [8]

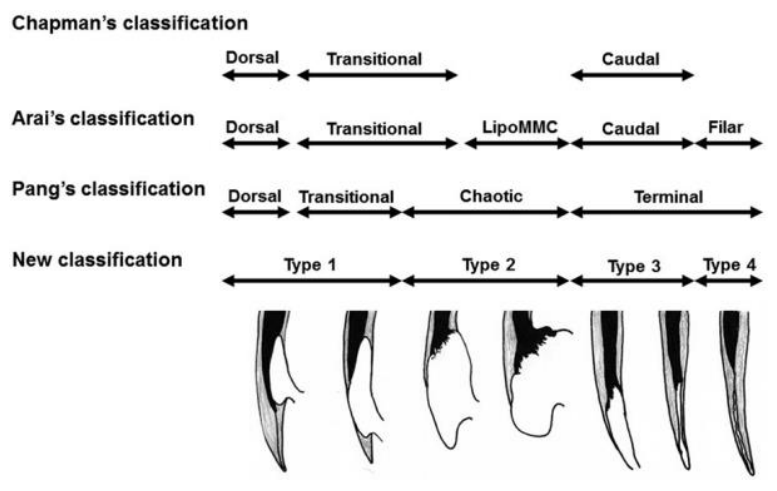




\section{Presenting concerns}

A 26-year-old female was admitted to the department of neurosurgery because of severe lower back pain and weakening of both legs with pain. She complained of urinary incontinence.

\section{Clinical findings}

Hypertrichosis in the lumbar region, sensory deficit in the feet and perineum and motor weakness of both feet were all recorded during the physical examination. All modalities of sensation were diminished in dermatomes L4, L5, S1 on both sides. Right sided foot drop was observed. The muscle power of dorsiflexion was specified as 3+ on the Medical Research Council Scale (MRC) on the right and 5 MRC on the left side. Bilateral pes cavus was presented.

\section{Diagnostic focus and assessment}

An MRI of the lumbosacral region showed dilatation of the spinal canal in the lumbosacral region, spinal cord extension up to $\mathrm{S} 2$ with an intra and extradural lipoma extending to the subcutaneous tissue through the spina bifida (Fig. 1-3).

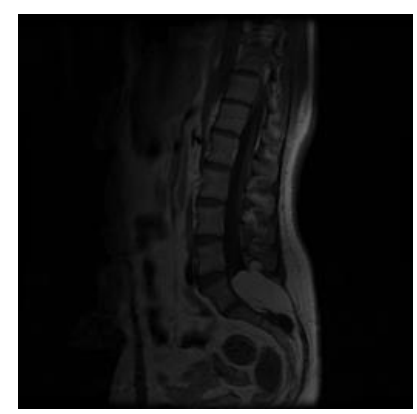

Fig. 1. Magnetic resonance of lumbar spine T1 sequence, midline sagittal section with large lipoma and low-lying conus medullaris.

Ryc. 1. Rezonans magnetyczny w sekwencji T1 w przekroju strzałkowym obrazujacy tłuszczak o dużych rozmiarach z nisko położonym stożkiem rdzenia.

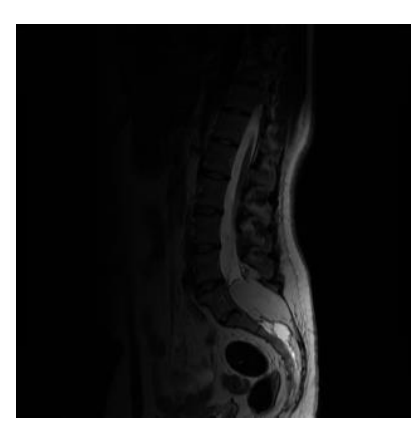

Fig. 2. Magnetic resonance of lumbar spine T2 sequence, midline sagittal section with large lipoma and low-lying conus medullaris.

Ryc. 2. Rezonans magnetyczny w sekwencji T2 w przekroju strzałkowym obrazujący tłuszczak o dużych rozmiarach z nisko położonym stożkiem rdzenia.

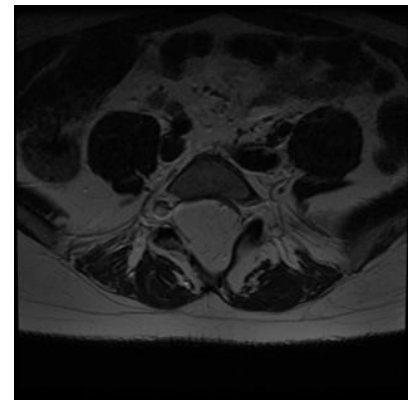

Fig. 3. Magnetic resonance of lumbar spine T2 sequence, axial section on the level of S2 with large lipoma filling whole spinal canal.

Ryc. 3. Rezonans magnetyczny odcinka lędźwiowego kręgosłupa w sekwencji T2 w przekroju poprzecznym na poziomie S2 obrazujący rozległy tłuszczak wypełniający cały kanał kręgowy.

The ultrasonogram showed a significant amount of postvoidal residual urine.

\section{Therapeutic focus and assessment}

The total intravenous anesthetic technique using infused propofol with alfentanil and midazolam was employed in the course of the surgery. A single bolus of Atracurium was used to initially induce skeletal muscle relaxation in the patient. This kind of anesthesia was crucial for intraoperative monitoring.

The patient was in the prone position. Laminectomy at the L5, S1 and S2 levels was performed. Consequently, the dural sac was opened over the lipoma.

Untethering of the cord was performed by removing the subcutaneous, intracanal extradural part of the lipoma and most of the intradural lipoma. The thickened filium terminale was dissected and the conus medullaris was released.

The most challenging part of the surgery was removing the lipoma by localizing the neural structures and preserving their structural integrity. Intraoperative monitoring is one of the most important tools during tethered cord surgery.

Spontaneous EMG (sEMG), trigged EMG (tEMG) and somatosensory evoked potentials (SSEP) were all employed during surgery.

Somatosensory evoked potentials provides monitoring of the dorsal column of the spinal cord. Posterior tibial nerves (L4, L5, S1) were used for monitoring in the lower extremities. Somatosensory evoked potentials involves electrical stimulation of the sensory and motor fibers caudal to the region of the spinal cord at risk. Simultaneously, it records this signal rostral to the region at risk, in this case at the scalp [7].

Spontaneous EMG was used to monitor the nerve roots responsible for muscle innervation. Spontaneous activity was measured with electrodes placed in the muscle of interest and no stimulation was performed. Surgical manipulation produced neurotonic discharges and activity in the corresponding innervated muscles [7]. 
In the tEMG technique a monopolar electrode is used to stimulate a suspected region of the neural structure e.g. the nerve root. In the above case, special care was taken to differentiate the filium terminale - thicker and iridescent white - from the nerve root. After meticulous hemostasis, the dural sac was closed watertight using running suture tissue glue and autologous fascia.

\section{Follow up and outcomes}

After two weeks the patient was admitted to hospital because of large cerebrospinal fluid collection under the skin in the region of the surgery (Fig. 4, 5).

One month after the operation lower back pain and bladder control improved significantly.

Sensory function in both lower limbs improved and sciatica relieved completely. The right sided foot drop remained unchanged.

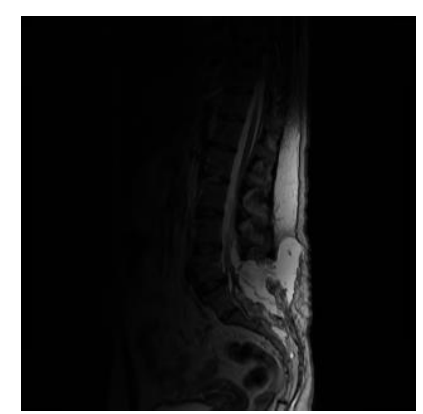

Fig. 4. Magnetic resonance of lumbar spine T2 sequence, midline sagittal section with cerebrospinal fluid collection and stage of lipoma resection. Ryc. 4. Obraz rezonansu magnetycznego odcinka lędźwiowego kręgosłupa w sekwencji T2 w przekroju strzałkowym obrazujący torbiel płynową po usunięciu thuszczaka.

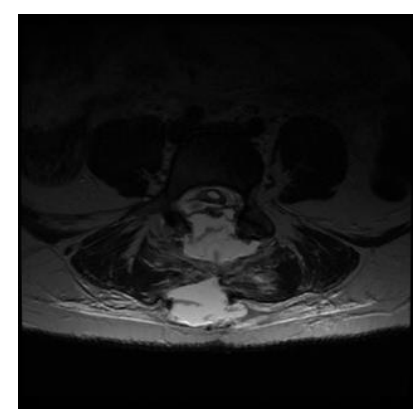

Fig. 5. Magnetic resonance of lumbar spine T2 sequence, axial section with cerebrospinal fluid collection and stage of lipoma resection.

Ryc. 5. Obraz rezonansu magnetycznego odcinka lędźwiowego kręgosłupa w sekwencji T2 w przekroju poprzecznym obrazujący torbiel płynową po usunięciu tłuszczaka.

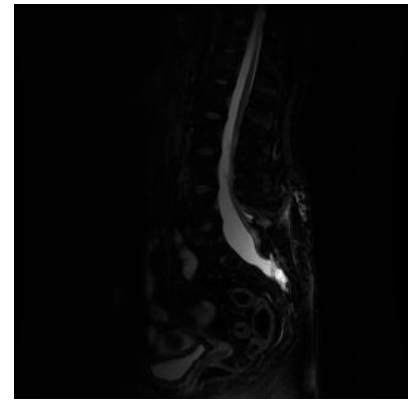

Fig. 6. Magnetic resonance of lumbar spine T2 sequence, midline sagittal section, with visible postoperative image of lipoma resection and without fluid collection.

Ryc. 6. Obraz rezonansu magnetycznego odcinka lędźwiowego kręgosłupa w sekwencji T2 w przekroju strzałkowym z widocznym pooperacyjnym obrazem usuniętego tłuszczaka bez kolekcji płynowej.

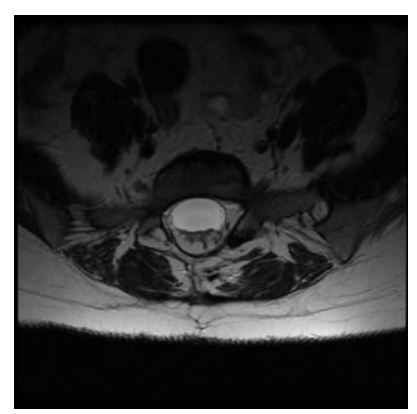

Fig. 7. Magnetic resonance of lumbar spine T2 sequence, axial section Ryc. 7. Obraz rezonansu magnetycznego odcinka lędźwiowego kręgosłupa w sekwencji T2 w przekroju poprzecznym.

\section{From patient's perspective}

From the patient's perspective, the time of suffering this condition without diagnosis was the most inconvenient. Despite the very alarming manifestation of TCS she was treated for approximately half a year before MRI.

Her expectations about the surgery were unrealistic. The patient expected complete relief of the symptoms, and she still suffers from (three years after surgery) right-sided foot drop.

\section{DISCUSSION}

There are many papers with case reports concerning tethered cord syndrome although it is rarely found in adults. The authors' intention was to draw attention to characteristic aspects of this condition. 


\section{Diagnostics}

Our case shows the importance of fast diagnostics, the lack of which may be acutely problematic for a patient. Every sciatica or low back pain which lasts longer than one month should be diagnosed with an MRI scan $[9,10]$. The above mentioned rule should be fundamental in spine diagnostics. If a patient presents neurologic deficits like foot drop or incontinence, diagnostics should be performed immediately.

The triad of characteristic for TCS features in MRI are:

1) thick filium terminale $>2 \mathrm{~mm}$,

2) elongated spinal cord,

3) posterior displacement of conus medullaris with the filium terminale pressing against the posterior wall of the spinal canal in the vicinity of L5 lamina [11].

\section{Qualifying for surgical treatment}

Surgery qualification is the next step in managing TCS. This is a crucial step in a surgeon's everyday practice. Unthetering the cord is not directly recommended for all the patients with TCS. However, patients with a significant abnormality and clear clinical deterioration are the most straightforward surgical candidates as in such a situation as the benefits from surgery outweigh the risks [12].

Slow but persistent deterioration makes the decision about, surgery much more difficult particularly in terms of timing. Delaying the surgery until a safe time seems to be a reasonable alternative [12].

The issue of a neurologically normal patient with abnormal MRI findings is yet another problem to be discussed. Careful observation with an intervention plan in case of deterioration in terms of neurological status of the patient is the only reasonable approach in such conditions.

\section{Surgery}

Stabilization of or improvement in the neurological deficits in symptomatic patients and prevention of future deficits in asymptomatic patients are essential aims of surgical intervention. Untethering the cord during surgery is crucial.

The relationship of the lipoma to the spinal cord and surrounding nerve roots is irregular and asymmetrical. Patients with large lipomatous components may be a particular challenge for surgical treatment. In such situations, total untethering of the cord or entire lipoma resection may be impossible. In consequence, it is better to perform partial untethering than risk serious neurologic complications like atonic bladder $[11,13]$.

Intraoperative neurophysiological monitoring (IONM) may help to protect functional nervous tissue and prevent postoperative neurological deficits $[8,13,14,15]$.

One the main features of tethered cord surgery is variable anatomy. It is often very difficult to differentiate and localize the nerve roots in a large mass of lipoma or scar tissue. Intraoperative neurophysiological monitoring helps to gain credible information on whether the structure we suspect to be filium terminale or other tissue without a neurological role is not a functional neural structure.

Somatosensory evoked potentials, sEMG and tEMG are the most important for the duration of TCS surgery. The last one is the most valuable according to the authors $[15,16]$.

The most important and the final part of the surgery is closure of the wound. Watertight closure has a pivotal role in preventing CSF leak. This complication in our case is difficult to prevent or treat. A thinned dura with a large defect is not a high quality material to preserve water tightness. Meticulous patching with autologous fascia or a dural graft with any of various fibrin preparations is an essential technique during wound closure [12].

\section{Postoperative period}

The early postoperative period may be often dominated by problems with wound healing and CSF leak. Over-sewing of the wound, CSF aspiration from the subcutaneous collection, inserting a lumbar drain or direct dural closure are crucial strategies to prevent CSF leak.

Follow up of the patient with successive MRIs and careful neurological examination are very important in the postoperative period. Properly conducted surgery guarantees marked clinical improvement, but re-tethering after the initial operation is not an infrequent problem.

\section{CONCLUSIONS}

Tethered cord syndrome is an absorbing surgical riddle, with much controversy. Proper surgical qualification, stabilization, improvement of the neurological deficits and prevention of future deficits in asymptomatic patients are the fundamental goals of the surgery. 


\section{Author's contribution}

Study design - R. Staszkiewicz, W. Marcol

Data collection - W. Och, R. Staszkiewicz

Data interpretation - W. Strohm, W. Marcol, R. Staszkiewicz

Statistical analysis - A. Kotas

Manuscript preparation - W. Marcol, R. Staszkiewicz, J. Miodoński

Literature research - R. Staszkiewicz, W. Marcol

\section{REFERENCES:}

1. Akay K.M., Ersahin Y, Cakir Y. Tethered cord syndrome in adults. Acta Neurochir. 2000; 142(10): 1111-1115.

2. Tubbs R.S., Oakes W.J. Can the conus medullaris in normal position be tethered? Neurol. Res. 2004; 26(7): 727-731, doi: 10.1179/016164104225017910.

3. Kanev P.M., Bierbrauer K.S. Reflections on the natural history of lipomyelomeningocele. Pediatr. Neurosurg. 1995; 22(3): 137-140, doi: 10.1159/000120891. 4. Yamada S., Colohan A.R., Won D.J. Tethered cord syndrome. J. Neurosurg. Spine 2009; 10(1): 71-80, doi: 10.3171/2008.10.SPI15714L.

5. Tubbs R.S., Wellons J.C. Tethered Spinal Cord: Fatty Filum Terminale, Meningocele Manqué, and Dermal Sinus Tracts. In: Youmans Neurological Surgery, $6^{\text {th }}$ Edition. H.R. Winn (Ed.) Elsevier, 2011, pp. 2227-2232.

6. Yamada S., Won D.J., Pezeshkpour G., Yamada B.S., Yamada S.M. Siddiqi J., Zouros A., Colohan A.R. Pathophysiology of tethered cord syndrome and similar complex disorders. Neurosurg. Focus 2007; 23(2): E6, doi 10.3171/FOC-07/08/E6

7. Oakes W.J. The borderlands of the primary tethered cord syndrome Clin. Neurosurg. 1996; 43: 188-202.

8. Morota N., Ihara S., Ogiwara H. New classification of spinal lipoma based on embryonic stage. J. Neurosurg. Pediatr. 2017; 19(4): 428-439, doi 10.3171/2016.10.PEDS16247.

9. Gonzalez A.A., Jeyanandarajan D., Hansen C., Zada G., Hsieh P.C. Intraoperative neurophysiological monitoring during spine surgery: a review. Neurosurg. Focus 2009; 27(4): E6, doi: 10.3171/2009.8.FOCUS09150.
10. Chou R., Qaseem A., Snow V., Casey D., Cross J.T. Jr, Shekelle P., Owens D.K. Diagnosis and treatment of low back pain: a joint clinical practice guideline from the American College of Physicians and the American Pain Society. Ann. Intern. Med. 2007; 147(7): 478-491.

11. Yamada S., Lonser R.R. Adult tethered cord syndrome. J. Spinal Disord. 2000; 13(4): 319-323.

12. Drake J.M. Surgical management of the tethered spinal cord--walking the fine line. Neurosurg. Focus 2007; 23(2): E4, doi: 10.3171/FOC-07/08/E4.

13. Paradiso G., Lee G.Y., Sarjeant R., Hoang L., Massicotte E.M., Fehlings M.G. Multimodality intraoperative neurophysiologic monitoring findings during surgery for adult tethered cord syndrome: analysis of a series of 44 patients with long-term follow-up. Spine 2006; 31(18): 2095-2102, doi: 10.1097/01.brs.0000231687.02271.b6.

14. Pouratian N., Elias W.J., Jane J.A., Phillips L.H., Jane J.A. Sr. Electrophysiologically guided untethering of secondary tethered spinal cord syndrome. Neurosurg. Focus 2010; 29(1): E3, doi: 10.3171/2010.3.FOCUS09299.

15. Sala F., Squintani G., Tramontano V., Arcaro C., Faccioli F., Mazza C. Intraoperative neurophysiology in tethered cord surgery: techniques and results. Childs Nerv. Syst. 2013; 29(9): 1611-1624, doi: 10.1007/s00381-013-2188-3. 16. Husain A.M., Shah D. Prognostic value of neurophysiologic intraoperative monitoring in tethered cord syndrome surgery. J. Clin. Neurophysiol. 2009; 26(4): 244-247, doi: 10.1097/WNP.0b013e3181b2edae. 